\title{
THE DEVELOPMENT OF MARX'S CONCEPT OF ALIENATION: AN INTRODUCTION
}

\author{
Lanny Ace Thompson* \\ University of Kansas
}

Mid-American Review of Sociology, 1979, Vol. IV, No. 1:23-38

\begin{abstract}
The paper presents an introduction to and summary of the concept of alienation as found in the works of Karl Mlarx, from a developmental perspective. Five separate works, ranging from his early to later writings, are discussed. The paper argues that Mlarx's concept of alienation is a continuous clarification and expansion of ideas first put forth in 1844. His development in economics supports and qualifies his assertions of a more philosophical nature. The early and later works should neither be understood as having complete continuity nor complete incompatibility, for the later grew out of the earlier.
\end{abstract}

Begimning with the belated publication of the Economic and Milosophical Mamscripts of 1844 (in German, 1939), students and proponents of Marx have disagreed on the correct interpretation of this work in the context of his later writings. Central to this discussion is the debate over the importance of alienation in the whole. of Marx's thought. Some argue that this concept is a philosophical apparition of the young idealist still being persuaded by Hegel, only to be abandoned by the mature, scientific Marx (Hook, 1962; Althusser, 1970). This point is contested by those holding that this concept is found throughout Marx's writings (Avineri, 1968; McLellan, 1970). Ollman (1971) and, especially, Meszaros (1972) have dispelled the abandonment thesis although it still exists in various forms (LeoGrande, 1977). What is still lacking is a treatment of alienation that clearly outlines a developinent of Marx's thought. Meszaros is intent on showing that alienation is a concept in each of the major works, but tends to see them in an aggregate and somewhat static fashion. Ollman falls into the same tendency, admitting that his book is

- Thanks to my mentor, Dr. Alan Sica. 
"a-historical." This paper presents an introduction to and summary of the concept of alienation as found in Marx from an explicitly developmental perspective. I will trace the concept through five of his works: 1) Economic and Philosophical Mamuscripts of 1844 (Paris Manuscripts); 2) "Theses on Feuerbach" (1845); 3) The Germant Ideology (1845-46); 4) Gnuidrisse (1857-58); and Capital (1867).

The precendene for Marx's theory of alienation is found in the philosophy of G. W. F. Hegel and in the materialist critique of Hegel by Ludwig Feuerbach. In the chapter "Estranged Labour" in the Paris Manuscripts, Marx makes liberal use of the phrases "species-activity", "species-being", "human essence", etc. These are borrowed from Feuerbach who had presented his influential critique of Hegel in The Essence of Cliristianity (1841). Hegel believed that there was a universal Absolute (Mind or Idea) and that man was Mind in a self-alienated state. The progression of history was a dialectical movement in which man increased his consciousness of the Idea. The development of man was the actualization of the Mind becoming fully "self-conscious", universally conscious. This was a philosophical and speculative conception of man. Feuerbach took a humanistic approach in refuting Hegel's concept of the Idea as being metaphysically "above" man. He began by asserting that religion and the concept of God were simply the projection and the consequent estrangement of man's essence, i.e., his species-being, which was the sum total of the inherent nature of humans. These attributes were the generic qualities of mankind. God was man's being that has been externalized, objectified and now stands in opposition to him. God was man in his self-alienation; God was man's relinquished self. Thus man is divided against himself, i.e., alienated. Hegel's concept of the Idea was criticized as also being a projection of species-being and thus no less theological. For Hegel, Mind (read "God") was being; man was the thought. However, with Feuerbach, man, specifically species-being, was the Absolute and God was the thought (Tucker 1967:85-89).

From Hegel, Marx extracts the notion of alienation as the scparation of subject from itself, with this estrangement existing dialectically, in contradiction. These antagonisms are a motive 
force of human history. Through the influence of Feucrbach, Marx understands alienation as the domination of a subject by an estranged object of its own creation. For Marx, this subject is man, specifically the worker, and the object is capital, including all its social relations.

Estrangement in the labor activity, writes Marx in the Economic and Philosophical Manuscript of 1844, involves first "The relation of the worker to the product of labour as an alien object exercising power over him" (Marx and Engels, 1974, v.3:275). The product that the worker creates is not his, but is appropriated by the capitalist. This product stands opposed to him as capital. Second, "... labour is external to the worker, i.c., it does not belong to his intrinsic nature; ... in his work, therefore he does not affirm himself but denics himself..." (Marx and Engels 1974 , v.3:274). Marx held that man differs from animals in that he has consciousness. In his work he objectifies this consciousness, he duplicates himself in the world of objects. Man's powers and "nature" are transformed into objects, into material creations. His skill, ingenuity, values, etc., become realized through this life activity. Unlike animals, men produce cven in the absence of immediate physical need. When an animal produces, its product is immediately used to fulfill a subsistence need; its activity is dictated by instinct. Man produces willfully and confronts his product freely. This product has a use-value, i.e., it has the capacity to satisfy a human want. Man decides how and when it is to be used. But wage labor reduces not only his product, but also his labor into a commodity that is controlled by another person. The product is no longer valued for its use, but for its worth on the market, i.e., its exchange-value. Labor, too, is transformed into a commodity because now it has exchange-value (wages) and becomes an abstraction measured by money. Human capacities are abstracted and quantified through the assigninent of a monetary value. In unalienated labor use-value is created for its own sake, to be used. But in wage labor, value is created only to be transformed to exchange-value. $A$ coat has a certain use-value. It was produced by a man and it is an objectification of his labor. For example, its design, pattern, color and intended use reflects the worker's consciousness, while its craftsmanship reflects his 


\section{Mid-American Review of Sociology}

real, human powers. In capitalist production the coat is only valued for its exchange-value. The product is not controlled by the workers, but by the capitalists. This product, capital, is no longer the workers' but subordinates thein for its own purposes. The design of the manufacturing process controls the workcrs, i.e., their labor conforms to the division of labor. Their motions are not self-determined but directed by the capitalist who has purchased their labor, thus controlling it and its product. The worker exchanges labor for the means of subsistence. Wage labor is a process of adaptation, of necessity, and therefore it is forced rather than voluntary. Labor is not an end, but a means. It is a "servant of the wage." Continuing, Marx writes,

Estranged labour turns thus: (3) Man's species-being ... into a being alien to him, into a means for his individual existence... (4) An immediate consequence of the fact that man is estranged from the product of his labour, his life activity, from his species being, is the estrangement of man from man (Marx and Engels, 1974, v.3:277).

The meaning of "species-being" in this passage should not be understood in the Feuerbachian sense. In this same section, Marx clearly defines it through the means of a comparison.

...the productive life is the life of the species. It is life-engendering life. The whole chasacter of a species-its species-character-is contained in the character of its activity; and free, conscious activity is man's species-character .... The animal is immediately one with its life activity. It does not distinguish itsclf from it. It is its life activity. Man makes his life activity itself the object of his will and of his cousciousuess. He has conscious life activity. It is not a determination with which he directly merges. Conscious life activity distinguishes man immediately from animal life activity. It is just because of this that lye is a species-being (Marx and Engcls, 1974, v.3:276).

Except for an occassional occurrence in Grindrisse (Marx, 1973:243, 496) Marx discontinues the use of "species-being" in 
1845. In the Cerman Ideology, however, he makes it known why he has altered his lcxicon.

... [T the traditionally occuring philosophical expressions such as "human essence," "species-being," etc., gave the German theoreticians the desired season for misunderstanding the real trend of thought and believing that here again it was a question of mercly giving a new turn to their worn-out theoretical garment (Marx and Engels, 1974, v.5:236).

If Marx had originally adopted the Feuerbachian notion of human essence intact, then his Paris Manuscripts could rightly be called ideological (or bourgeois) because they were based upon an idealist speculation as to the metaphysical nature of man. The manuscripts would also be fundamentally different from his later works. Rather. Marx empirically observes that man's only nature is simply that he has a socially conditioned consciousness and that he proves this consciousness through labor. It is in the shaping of nature through work, the creation of a world of objects, that man proves his species-being, i.c., his humanness. Thus species-being for Marx is not the species-being in the Feuerbachian usage.

The consequence of estranged labor is man alicnated from his species-being -he no longer produces in a way characteristic of the human species. Life has been reduced to an animal existence. The absence of such alienation would be a condition in which he objectifies himself in all products, in which these objects confirm and realize his individuality. They become his objects. Such potential can only be realized in society, man interacting with man. Marx writes in the Paris Manuscripts,

... [W] hen I am active scientifically, etc. an activity which I can seldom perform in direct community with others-then my activity is social, because 1 perform it as a man. Not only is the material of my activity given to me as a social product (as is even the language in which the thinker is active): my oun existence is social activity, and therefore that which I make of myself, I make of mysclf for society and with the consciousness of myself as a social being. My general consciousness is only the theoretical shape of that of which 
the living shape is the real community, the social fabric, although at the present day general consciousness is an abstraction from real life and such confronts it with hostility (Marx and Engels, 1974, v.3:298).

Humar existence is social existence. Humans have consciousness and objectify it through labor. This consciousness is a social product in that it can only arise through the interaction of men. As we have seen, wage labor alienates man from his product and his labor. The abstraction, of human powers through money further alienates man from his species-being and from other men. Money itself becomes the social bond thus alienating man from man. Men no longer relate to each other on the basis of real qualities, but rather according to abstractions. "Thus what I am and am capable of is by no means determined by my individuality" (Marx and Engels, 1974, v.3:324). Money turns the concrete ability of man into an alienated power belonging to its possessor.

I am brainless, but money is the real brain of all things and how then should its possessor be brainless. Besides, he can buy clever people for himself, and is he who has power over the clever more clever than the clever... Docs not iny money, therefore transform all my incapacities into their contrary? (Marx, 1974, v.3:324).

Thus, in the Economic and Philosophical Mamuscripts of 1844, alienation is four-dimensional: Man is separated from his product, his labor, himself and others. Man is not alienated because wage labor separates him from his general abstract species-being. Rather, he is a social being that creates and appropriates nature in the forms of objects according to his consciousness which is a result of social life. He is alienated when he is scparated from these relationships. Man's life activity is conscious production, but the concepts, methods, and materials are presented as a given of a particular mode of existence that is social "... J/ust as socicty produces man as man, so is society produced by him" (Marx and Engels, 1974, v.3:298). 
In 1844 Marx expressed the importance of man's activity in the material world. Labor is an objectification of his consciousness. This conceptualization of the world was a result of human interaction and thus a social "product." In 1845 in the "Theses on Feuerbach," these ideas appear in a concise, succinct form. Marx first criticizes Feuerbach for failing to see human activity as objective activity. Previous materialism had only considered the object of contemplation. Marx points out that through his activity man alters the environment and thus alters the objects of contemplation. Thus, human activity must be considered as objective activity. He also very explicitly attacks Feuerbach's notion that the essence of man is an abstract Absolute posited in isolated individuals. On the contrary, man's essence is the ensemble of his social interactions. Thus, the "Theses" entail a systematic clarification of ideas already introduced, and to be developed later.

As in the Paris Manuscripts, passages in The German Ideology distinguish men from animals by their consciousness. Due to the polemicalnature of this volume Marx's notion of consciousness may be misconstrued to mean that it is a simple mirror image or ideological reflex of material life. Certain isolated passages may lend themselves to such an interpretation, but this is a mistaken one.

The production of ideas, of concepts, of consciousness, is at first directly interwoven with the material activity and the material intercourse of men-the language of real life. Conceiving, thinking, the mental intercourse of men at this stage still appear as the direct effux of their material behavior. The same applies to mental production expressed in the language of the politics, laws, morality, religion, metaphysics, etc., of a people. Men are the producers of their conceptions, idcas, etc., that is, real active men as they are conditioned by a definite development of their productive forces and of intercourse corresponding to these... (Marx and Engles, 1974, v.5:36).

The confusion originates in an undialectical interpretation. The formation of human awareness is not a one-way, causal 
process. It arises out of social interaction. Men are not merely products of their circumstances, they also create their circumstances. Consciousness is a social product only in that it can emerge exclusively from the intercourse of men. Since men are born into a society, they cncounter pre-existing material conditions. Hence these conditions exist "independently of their will." But this does not lock them into determunism because they still enter into interaction, developing their means of production. Consciousness is "at first" directly interwoven with material life. Marx cstablishes that when a certain stage of productive capacities has developed a mental division of labor occurs, allowing the emancipation of consciousness from the material world. Whereas the idea of communism has been expressed many times throughout history, the material elements of this revolution must be present for its actual realization. Marx also expresses this idea in Grundrisse, and later in Capital.

The life-process of society, which is based on the process of material production, does not strip off its mystical veil until it is treated as production by freely associated men, and is consciously regulated in accordance with a settled plan. This, however, demands for society a certain material groundwork or set of conditions. .. (Marx and Engels, 1972:223).

Marx held that men could be aware of the dialectical process and change the world through revolutionary practice. Man is able to grasp his history as a process. If all consciousness was a material reflex then Marx would have to subject himself to his own criticism. However, only ordinary consciousness is to be criticized. Religion, metaphysics, morality, etc., were all types of ordinary consciousness, i.e., ideology. This was rejected as being the reflection of the material world because it was speculative, or as in Feuerbach, because it failed to recognize human activity itself as objective activity. Marx's basis was real, active men, empirically observed.

Marx had broken with speculative philosophy in the Paris Manuscripts. His emphasis had been upon real man in the material world. He broke with his philosophical lexicon in 1845, criticizing 
it in The German Ideology, while clarifying his ideas on historical materialism. The social relations that resulted in consciousness were now recognized as limited (rather than determined) by the conditions of the development of productive forces. This follows from Marx's new materialistic conception that a certain organization of production is combined with a certain mode of cooperation, or social relations with this social stage itself constituting a productive force. This aggregate of technological and social productive forces thus shapes the condition of social interactions. "... [T] he 'history of humanity' must always be studied and treated in relation to the history of industry and exchange" (Marx, 1974, v.5:43). The importance of human activity as objective ("objectifying") activity had already been clarified in the "Theses." In The German Ideology men continue to be seen as the result of social relations. However, Marx now posits the basis of social intercourse in the particular historical stage of social production. The shape of men's interaction has undergone a qualitative change through the discovery of historical materialism, but this is the logical outgrowth of his earlier conception of man as a social and productive being.

While the origins of man's "essence" have been clarified, the nature of alienation remains essentially the same. In alienation, as before, labor has lost the characteristic of being "self-activity" because material life becomes the end while labor is the means. Man now opposes his own productive forces in an objectified and expropriated form. These forces no longer belong to the workers, but to the capitalists. The worker is subordinated to the extreme division of labor; he has become fragmented, abstracted, alienated. In the production process the worker's tasks are fragmented into meaningless motions. When money becomes the basis of interaction, actual human powers are abstracted, i.e., distorted. Thus the worker is estranged from his labor, his product, himself, and other men (Marx and Engles, 1974, v.5:86-87). The four dimensions of alienation are still present. The term "productive forces" substituted for "labour" is a more economistic usage but it does not change the essential idea. This phrase anticipates a change that is realized by Marx around 1857 . 
We now leap a decade, most of which was a period of economic study for Marx, to Grundrisse. The work consists of a series of seven notebooks written between 1857 and 1868 representing 15 years of economic study. The notebooks were written as a project of self-clarification and contain Marx's synthesis, the basic outline ("grundrisse") of his mature economic thought. Upon these foundations Marx had projected a series of six books. Each book was to be an elaboration of an aspect of his critique of political economy. The volumes were to be written on: 1)Capital; 2) Landed Property; 3) Wage Labour; 4) the State; 5) International Trade; and 6) World Market. The volumes of Capital represent a partial completion of only onc of these projects. For this reason Grundrisse gives insight into the whole of Marx's later development (see forward by Nicolaus in Marx, 1973).

Bourgcois political economy, and Marx's carly cconomics, had been based upon the law of supply and demand and Ricardo's theory of value. In this economic analysis the workers received a "fair" wage as detcrmined by market prices. Capitalists and workers entered into a reciprocal exchange of commodities: wages were exchanged for labor. This labor was considered a commodity with an exchange-value like any other inanimate object. The advantage gained by one person over another was due to his superior skill and judgement in the marketplace, not to any inlicrent social relationship. The value of labor was considered equal to the wages it received; the relation between capital and labor constituted an exchange of equivalents. The value of labor (its output, or product) supposedly was accurately expressed as wages. However, in this scheme neither the source of profit nor the tendency of capital to increase and concentrate could be adequately explained. If the capitalist gained an advantage over the worker because of his efforts as a market-wise individucl, how then did a socicty's capital accumulate in the hands of a capitalist class; (sec forward by Nicolaus in Marx, 1973).

In Grundrisse, Marx made an important economic discovery. Labor, he pointed out, was a mique commodity because it was value-creating activity. The phrase "labour power" signified this new conception. Labor power is a use-value for the capitalists 
because of its capacity to create new exchange value. They are able to use this unique commodity, living labor power, to create new value: objectified, stored value, i.e., capital. For example, a capitalist purchases labor to turn cotton into cloth. The resulting value in this production process, the cloth itself, is sold to make a profit. In order to make this profit, the capitalist must first regain the costs of production (the expense of the unspun cotton, use of the looms, etc.) as well as the cost of the wages paid to the workers. But according to the theory of surplus value, this trade between capitalists and workers is an uneven one because the wages paid out have less value than the exchange-value that the latter have created. This difference is surplus value. It is that portion of capital created by the workers but expropriated by the capitalists. For example, when it takes 6 hours for a worker to produce exchange-value equivalent to his living needs and he is paid a living wage, then the 2 extra hours he works (assuming an 8 -hour day) becomes value for the capitalist. Surplus value is simply objectified surplus labor; it is that portion of capital produced by workers, but expropriated by the capitalists. Once in their hands, it becomes new capital and thus the source of profit. This relationship between capitalists and workers is a social relation, a mode of production and exchange inherent in the system of capitalism.

When the worker enters into wage labor, the capitalist gains control of labor's activity and its product. Marx states in Grundrisse:

The product of labour appears as alien property, as a mode of existence confronting living labour as independent. . and establishes itself opposite living labour as an alien power...(Marx, 1973:453-4).

As a consequence of the process of the accumulation of surplus value, it is the worker's own product, capital, that confronts them as stored labor existing for the benefit and use of the capitalists. Since the capitalist class dominates the world of capital, it can, for the most part, influence its distribution and use. Furthermore, since the workers own no tools or other means of 
production, they cannot survive without entering into a relationship with capital. In order to realize itself, labor must alienate itself. Capital stands against the workers, objective labor against living labor, value against value-creating activity. As a consequence of all of this, the worker does not exist as an end in himself and for himself, but separated from and against himself.

Living labour therefore now appears from its own standpoint as acting within the productiont process in such a way that, as it realizes itself in the objective conditions, it simultaneously repulses this realization from itself as an alien reality, and hence posits itself as insubstantial, as mere penurious labour capacity in the face of this reality alienated (entfrendet) from it, belonging not to it, but to others; that it posits its own reality not as a being for it, but merely as a being for others, and hence also as mere other-being (Anderssein), or being of another opposite itself (Marx, 1973:454).

In Marx's previous concept, the chief antagonism was between capital (which was a falsified manifestation of labor) and the real, natural social quality of labor as an objectification of man's life activity. His concept of alienation is given accuracy and depth by the discovery of capitalist production. With the theory of surplus value the chief antagonism is between stored labor controlled by the capitalists subordinating living labor for its own uses-the expansion of value. Marx's "philosophy" is qualified by his conomics. The new emphasis on surplus value in Grundrisse is not to the exclusion of the previous antagonism, for the cxchange relations of wagc labor are a necessary pre-condition and source of alicnation.

The general cxchange of activities and products, which has become a vital condition for each individual-their mutual interconnection-here appears as something alien to them, autonomous, as a thing. In exchange value, the social connection between persons is transformed into a social relation betwcen things; personal capacity into objective wealth (Marx, 1973:157). 
In Grundrisse Marx's concept of alienation appears fully develuped. Its four dimensions (separation of the worker from his labor, product, himself, and others) are apparent. He has not diminished his concept, but rather built upon it. His mature economic theory leads to a more accurate model of capitalist alienation.

In Capital the mention of alienation is limited, but not non-existent. Knowing, first of all, that Marx discusses it in Grundrisse, and secondly, that it is in fact present in Capital proves that he had not abandoned it altogether. Of Marx's six projected books, one was to be on capital. It was to consist of four sections: a) capital in general; b) competition; c) credit; d) share capital, as the most complete form (turning over into communism), together with its contradictions. The first, "capital in general" was to be subdivided into: 1) Value; 2) Money; 3) Capital. Thus the three extended volumes of Capital are the completion of only one section ("capital in general") of the first book on capital, which was to be the first of a series of six books (see forward by Nicolaus in Marx, 1973). Marx did not elaborate on alienation in Capital because it was not the place to do so. The book on wage labor or the subdivision on the "turning over to communism" were such places. The discussions in Crundrisse, his outline, and to a limited degree in Capital prove that he still had the concept firmly in mind.

When discussing alienation in Capital, Marx cxplicitly treats the separation of the worker from his product and labor.

First, the labourer works under the control of the capitalist to whom his labour belongs. ... Secondly, the product is the property of the capitalist and not that of the labourer, its immediate producer. . (Marx and Engels, 1972:238).

Since before entering on the process, his own libbour has already been alienated from himself by the sale of his labour-power, has been appropriated by the capitalist and incorporated with capital, it must, during the process be realized in a product that does not belong to hin.... The labourer therefore constantly produces 
matcrial, objective wealth, but in the form of capital, of an alien power that dominates and exploits him... (Marx, 1889:583).

Only implicitly, in his concept of the fetishism of commodities does Marx present the aspect of alienation of men from men. It recalls earlier discussions critical of money and exchange relations. The world of commodities, the relation of things to things in which products appear as sui generis, is termed the fetishism of commodities.

A commodity is therefore a mysterious thing, simply because in it the social claracter of men's labour appears to them as an objective character stamped upon the product of that labour; because the relation of the producers to the sum total of their own labour is presented to them as a social relation, existing not between themselves but between the products of their labour (Marx, 1889:42-3).

Here we have the dimension of the estrangement of men from men. The fetishism of commoditics masks the social relations of man and sets up the relation between things. The value-relations of commodities do not have direct connection to their use-value. Men relate to each other on the basis of abstraction, not the real, material relation between themselves. The objectified labor of individuals is not a basis for their inter-relation because it has been transformed into capital. The existence of capital means the alienation of the worker from his product, his labor, and others. Notably absent is the estrangement of man from himsclf. But as already established, Cipital cannor be considered a work on alicnation, and since this dimension does appear in Marx's outline there is no reason to believe he discarded it.

In conclusion, I would explain the development of Marx's thought as follows. In the Paris Manuscripts he presented his four dimensional concept of alienation which included a concept of human nature. The importance of man's practical activity in the world was emplasized. This activity involved the objectification of his consciousness througl labor; in turn this consciousness was considered to be a result of social interaction. In the "Theses on 
Feucrbach" Marx clarifies the importance of human activity and deems it objective activity. Consciousness is again attributed to social interaction. In the German Ideology, he builds upon the idea that man is a social and productive being, noting that social activity itself is conditioned by the particular development of productive forces. Throughout this development, alienation is a function of being estranged from one's product, labor, himself and his social relationships. This is a result of capitalist exchange relations. In Crundrisse Marx makes the discovery of surplus value, thus adding depth to the concept of alienation. It is a more accurate and complete statement of the process of cstrangement in capitalist production. Whereas before wage labor was criticized as alienating due to transformation of objective relationships into abstract ones, Grundrisse points out additionally the opposition of value to living labor. The concept of alienation remains four dimensional, but the basis is more fully developed, reflecting the maturation of Marx's economics. Capital is a painstaking elaboration as to the nature of capital in general, not to be considered a full treatment of alienation. It presupposes previous work, especially Grundrisse, and cannot be viewed out of this context. The thought of Karl Marx should be seen as a continuous expansion and clarification of idcas first put forth in 1844. His development in economics supports and qualifies his assertions of a more philosophical nature. The early and later works should neither be considered as having complete continuity nor complete incompatibility, for the later grew out of the earlier.

Alth usser, Louis

\section{REFERENCES}

1970 For Marx. New York: Vintage Books.

Avincri, Shlomo

1968 The Social and Political Thought of Karl Marx. Cambridge:

Cambridge University Press.

Hook, Sidncy

1962 From Hegel to Marx. Ann Arbor: University of Michigan Press.

LeoGrande, William

1977 "An investigation into the 'Young Marx' controversy" Science and Society XLI (2):129-151. 
Mid-American Review of Sociology

McLellan, David

Marx, Karl

1970 "Marx and the missing link" Encounter 35(5):35-45.

1889 Capital. London: Swan Sonneschein \& Co.

1973 Grundrisse. Translated and with a forward by Martin Nicolaus. New York: Vintage Books.

Marx, Karl and Frederick Engels

1972 Marx-Engels Reader. Robert Tucker, ed. New York: W.W. Norton and Co., Inc.

1974 Collected Works, volumes 3 and 5. London: Lawrence and Wishart Ltd.; and in collaboration with New York: International Publishers Co., Inc.; and Moscow: Progress

Mészáros, István Publishers.

1972 Marx's Theory of Alienation. New York: Harper and Row. Ollman, Bertell

1971 Aliention: Marx's Concept of Man in Capitalist Society. Cambridge: Cambridge University Press.

Tucker, Robert $C$.

1967 Philosophy and Myth in Karl Marx. Cambridge: Cambridge University Press. 